\title{
Tangence
}

\section{Malcolm Lowry's Vision of Vancouver}

\section{Tim Acton}

Numéro 48, octobre 1995

Montréal et Vancouver : parcours urbains dans la littérature et le cinéma

URI : https://id.erudit.org/iderudit/025860ar

DOI : https://doi.org/10.7202/025860ar

Aller au sommaire du numéro

Éditeur(s)

Tangence

ISSN

0226-9554 (imprimé)

1710-0305 (numérique)

Découvrir la revue

Citer cet article

Acton, T. (1995). Malcolm Lowry's Vision of Vancouver. Tangence, (48), 31-42.

https://doi.org/10.7202/025860ar d'utilisation que vous pouvez consulter en ligne.

https://apropos.erudit.org/fr/usagers/politique-dutilisation/ 


\section{Malcolm Lowry's Vision of Vancouver}

\section{Tim Acton}

Malcolm Lowry's works are at least in part autobiographical, but this does not diminish their importance as creative (if often incomplete) pieces. As Malcolm's brother Russell says in the preface to Anne Smith's collection of essays, "what we want is a better idea of what made him tick, and why." ${ }^{1}$ Exploring the complex web of biography, fiction, poetry, and letters allows us to achieve a fuller understanding of Malcolm Lowry and his works. For example, there is little doubt about how he felt about life at the edge of Burrard Inlet: his portrayals of Vancouver (and/or "Enochvilleport") are consistent in their condemnation of the city itself. Further, behind these descriptions lies a criticism of western civilization, of "progress" as a destructive force, yet these criticisms are set against the overwhelming joy that resulted from his life as a squatter on the shoreline of what is now Cates Park.

His marginal lifestyle set up an obvious dichotomy as Lowry attempted to enjoy a way of life and a location that came under the gaze of a nearby, expanding city. The existence was a precarious one with none of the amenities that most of us now take for granted. As well, the Lowrys lived on an inconsistent income, and threats of eviction were frequent and inevitable. This threat of dispossession from a location that he saw as paradisal appears in most of his fiction set on British Columbia's coast. With the imminence of expulsion and the resulting dislocation, it is not surprising that the journey serves as such an important theme in Lowry's fiction. Patricia Hunt, in "North American Pastoral: Contrasting Images of the Garden in Canadian and American Literature" has suggested that "The journey myth . . . (often a quest leading from the city toward not only wilderness and the middle landscape but also toward the values reposited in these landscapes) delineates an 'inner' territory of the psyche." 2 The comment seems particu-

1 Russell Lowry, "Malcolm-A Closer Look," Preface to The Art of Malcolm Lowry, Anne Smith ed., London, Vision, 1978, p. 13.

2 Patricia Hunt, "North American Pastoral: Contrasting Images of the Garden in Canadian and American Literature," American Studies, 23.1, Spring 1982, p. 41. 
larly appropriate to Lowry's self-reflexive (and self-defining) writing.

Hunt's comment also provides a useful context in which to analyze Lowry's descriptions of Vancouver. Sherrill Grace, for example, commenting on two films that she believes influenced Under the Volcano, remarks that "the landscape mirrors the turmoil of the soul at the same time as it appears to embody evil and hostile forces" (Grace's emphasis). ${ }^{3}$ Grace's terms are relevant to Lowry's vignettes of Vancouver as well because the hostile view of Vancouver is not so much a reflection of Lowry's attitude to the city as of his fears about losing the paradisal life. Thus, in a passage from "The Forest Path to the Spring" (henceforth "Forest Path"), the narrator defines destructiveness as a part of himself rather than an external force represented by the city (an impression given in many of his descriptions of "progress"). As the narrator is carrying firewood one evening, his lantern casts a shadow: "I saw my shadow, gigantic, the logs of wood as big as a coffin, and this shadow seemed for a moment the glowering embodiment of all that threatened us; yes, even a projection of that dark chaotic side of myself, my ferocious destructive ignorance." "Here, as Kathleen Scherf notes, "readers are forced to interact subjectively rather than objectively with Lowry's landscape." 5 The narrator's emphasis shifts quickly from a detached visual representation of his own shadow to the subjective psychological meaning with which he invests that shadow. In effect, he has altered the physical experience into an event of internal significance, a window to his psyche.

The descriptions of Vancouver found in Lowry's short story collection Hear Us O Lord from Heaven Thy Dwelling Place illustrate this subjective response and the appropriateness of Douglas Porteous's comment that "in modern literature, ... . the city has become metaphor rather than place, and in particular urban life is viewed as a complex metaphor for the human condition. " 6 In

3 Sherrill Grace, "Malcolm Lowry and the Expressionist Vision," The Art of Malcolm Lowry, Anne Smith ed., London, Vision, 1978, p. 105.

4 Malcolm Lowry, Hear Us O Lord from Heaven Tby Dwelling Place, Vancouver, Douglas \& McIntyre, 1987, p. 234.

5 Kathleen Scherf, The Collected Poetry of Malcolm Lowry, Vancouver, UBC Press, 1992, p. 16.

6 J. Douglas Porteous, "Deathscape: Malcolm Lowry's Topophobic View of the City, " Canadian Geographer, 31.1, 1987, p. 35. 
"The Bravest Boat," Vancouver is "Enochvilleport" with its "dilapidated half-skyscrapers, ... new beer parlors crawling with verminous light even in mid-afternoon and resembling gigantic emerald-lit public lavatories for both sexes, . . . totem pole factories, ... and other soulless behemoths," all housing "indescribable poverty and degradation, between which civic attractions were squeezed occasional lovely dark ivy-clad old houses that seemed weeping, cut off from all light, on their knees. " 7 Lowry also gives Enochvilleport a past, a time "seventy years before when the growing city was named "Gaspool." 8 This playing with the name allows Lowry to transform the historical "Gastown" into an image which, metaphorically, is an apt prelude to his descriptions of the outlying industrial locations.

In "Forest Path" there is a reference to "the city, with . . . its prison bars of Venetian blinds, its frozen static views of roofs and a few small dingy gardens." 9 Here the urban garden serves as a parody of the wilderness that, with the inlet, defined life at Dollarton. In his poetry; we find descriptions of "this pompous and joyless city" 10 and of "a place of fears": "Her conscience is in sad arrears / Repression rules with ugly leers." 11 "Lowry uses city images," then, as Porteous suggests, "as a shorthand, as symbols of despair, destruction, and death. . . . throughout the later works, whenever Lowry requires an image to indicate degradation or despair, he summons up city images. "12 The city is not simply a physical location but a repository for certain values of decay and repressiveness. When Hunt refers to the journey quest as a movement towards particular values assumed to reside in wilderness, she does not add the obvious assumption that the journey is also a movement away from the values of the metropolis, yet this duality is the most consistent feature of Lowry's descriptions of Vancouver and Dollarton.

Between the urban and rural settings we find the process of urbanization, and if the city is "soulless," degraded, and without

\footnotetext{
7 Lowry, Hear Us, p. 16.

8 Lowry, Hear Us, p. 13.

9 Lowry, Hear Us, p. 252.

10 Lowry, "Lament in the Pacific Northwest" [dated 1949-50], Collected Poetry, p. 190.

11 Lowry, "Noble City full of pigeons or everyone a hypocrite including me" [1940-54], Collected Poetry 199, lines 1, p. 7-8

12 Porteous, “Deathscape," p. 40.
} 
34

conscience, then the clearing of land represents the expansion of the city into the rural environment. In other words, urbanization is not a slow process of assimilation, but a rapid transfusion of values and a violation of that outer, peripheral world. In Lowry's depiction, the values are either rural or urban without gradations between the extremes. None of this is particularly new in literature or in discussions of our relationship with our environment, but Lowry's terms certainly define the process in a clear and unambiguous fashion. For example, up Burrard Inlet from Stanley Park one finds the industrialization that is set in ironic comparison with the standard promotional words of those who refer to "our expanding and fair city, ... the jewel of the Pacific," words that are quoted within "The Bravest Boat" to suggest the input of some entrepreneurial businessman or civic government representative. Lowry's narrator offers an alternative impression:

\begin{abstract}
[A]nyone who had ever really been in hell must have given Enochvilleport a nod of recognition, further affirmed by the spectacle, at first not unpicturesque, of the numerous sawmills relentlessly smoking and champing away like demons, Molochs fed by whole mountainsides of forests that never grew again, or by trees that made way for grinning regiments of villas . . . , mills that shook the very earth with their tumult, filling the windy air with their sound as of a wailing and gnashing of teeth. ${ }^{13}$
\end{abstract}

There is more in "The Bravest Boat": Lowry refers to "the tragic Seven Sisters, a constellation of seven noble red cedars that had grown there [in Stanley Park] for hundreds of years but were now dying," and he parenthetically adds that "They were dying rather than live longer near civilization." 14

In "Through the Panama" ("From the Journal of Sigbjorn Wilderness"), Sigbjorn reflects that

I believe you would never see in France, or among Frenchmen, the appalling sights of despair and degradation to be met with daily in the streets of Vancouver, Canada, where man, having turned his back on nature, and having no heritage of beauty else, and no faith in a civilization where God has become an American washing machine, or a car he refuses even to drive properly ... falls to pieces before your eyes. ${ }^{15}$

13 Lowry, Hear Us, p. 17.

14 Lowry, Hear Us, p. 13.

15 Lowry, Hear Us, p. 95. 
The distinction here is perhaps that between Old and New Worlds, for, as Porteous observes,

Lowry indicts machine civilization for its greedy, remorseless devastation of the natural, the organic. Unfortunately for Cana$\mathrm{da}$, this indictment, although meant to be general, is expressed by Lowryan protagonists wholly in Canadian terms. Canada, to Lowry in the 1940s, could still be redeemed; unlike Europe, or even the United States, its wilderness landscapes still remained relatively untouched. ${ }^{16}$

This is emphasized in the acknowledgement found in "The Bravest Boat" that the city is set in "a harbor more spectacular than Rio de Janeiro and San Francisco put together," ${ }^{17}$. but this is a reference to the harbour itself and not to the city, a distinction that is explored in the descriptions of what is happening beyond the city boundaries.

In "Present Estate of Pompeii," for example, Roderick Fairhaven refers to talk "that the forest would be slaughtered to make way for auto camps or a subsection." 18 Just as the urban garden serves as a parody of the wilderness found at Dollarton, the "auto camps" (also at Dollarton) serve as a parody of Lowry's own life as a squatter. There is a fine irony that civilization's approach is signalled by the creation of a campground where city dwellers can temporarily imitate a life of removal from the pressures of a job or the tyrannies of the clock-as long as one obeys the regulations regarding "check-out" time, of course, or remembers to return to the harness according to the dictates of that very job one is presumably escaping.

In "Forest Path," the narrator wonders if "civilization itself . . . had become conscious of the futility of pretending that it was advancing by creating the moribund, " 19 so that even the process of urbanization is seen as disharmonious and reflective of deathlike states. Hallvard Dahlie has suggested that Lowry was one of the few Canadian writers whose "search for an Eden ... was predicated on the premise that only an unspoiled wilderness, rather than a cultivated one, is worth attaining. " 20 Lowry's vision of

16 Porteous, "Deathscape," p. 42.

17 Lowry, Hear Us, p. 15.

18 Lowry, Hear Us, p. 181.

19 Lowry, Hear Us, p. 276.

20 Hallvard Dahlie, Varieties of Exile: The Canadian Experience, Vancouver, UBC Press, 1986, p. 60. 
36

paradise was one of harmony between people and their environment, but the city in his works represents that other human tendency to tame, control, and destroy.

Lowry's oft-quoted passage, "Civilization, creator of deathscapes, like a dull-witted fire of ugliness and ferocious stupidity ... had spread all down the opposite bank, blown over the water and crept up upon us from the south along it, murdering the trees and taking down the shacks as it went, "21 is one of the most forthright condemnations of the urbanizing process to be found in his work. Set in contrast to this demonic process which is given a life of its own is the view the narrator of "The Bravest Boat" enjoys of Lowry's own dwelling:

[N]early the only human dwellings visible on this side of the water that had any air of belonging, or in which their inhabitants could be said any longer to participate, were, paradoxically, a few lowly little self-built shacks and floathouses, that might have been driven out of the city altogether, down to the water's edge into the sea itself, . . . quite evidently built or placed with some human need for beauty in mind, even if under the permanent threat of eviction, and all standing .... as though in defiance of the town, before eternity. ${ }^{22}$

The city itself becomes a creature looming over the landscape, threatening, destroying. Yet there is Lowry's narrator, detached, looking out on Lowry's own little cabin and admiring its beauty. Significantly, the threat is not from the natural world but from the city, and the tone is contrary to that in a passage from "Gin and Goldenrod" where the narrator comments that, behind a subdivision, "was still the dark forest, waiting, one hoped, for revenge." 23 In "Forest Path," the idyllic images of the shacks perched on the inlet are repeated:

Standing there, in defiance of eternity, and yet as if in humble answer to it, with their weathered sidings as much a part of the natural surroundings as a Shinto temple is of the Japanese landscape, why had these shacks come to represent something to me of an indefinable goodness, even a kind of greatness? And some shadow of the truth that was later to come to me, seemed

21 Lowry, Hear Us, p. 276.

22 Lowry, Hear Us, p. 17.

23 Lowry, Hear Us, p. 206. 
to steal over my soul, the feeling of something that man had lost, of which these shacks and cabins, brave against the elements, but at the mercy of the destroyer, were the helpless yet stalwart symbol, of man's hunger and need for beauty, for the stars and the sunrise. ${ }^{24}$

One is reminded of Tony Bareham's observation that "For Lowry the dwelling place was a spiritual quest," 25 a quest that is defined in the narrator's suspicion that "in converting the very cannister I carried, the ladder down which I climbed every time I went to the spring-in converting both these derelicts to use I had prefigured something I should have done with my soul." 26 Kathleen Scherf's comment about the reader's subjective response to the Lowryan landscape is particularly appropriate here where the narrator has invested the objects with a significance that would not likely occur to the reader without the narrator's invitation to share his private and personal interpretation.

But one is also reminded of a description (written not about Lowry at all but about certain of V.S. Naipaul's characters) in which Richard Smyer refers to "the figure of the cultural castaway whose alienation from home and history threatens to drive him from a condition of desolation into despair and madness." 27 Or, as Ethan Llewelyn asks in October Ferry to Gabriola, "to be evicted out of exile: where then?" 28

Grace sees this struggle in terms of stasis and motion and contends that "Space, isolated from time, he repeatedly views as timelessness or stasis; stasis becomes hell or death, a condition of spatial enclosure, suffocation, and entrapment. The thrust of Lowry's art is to overcome space as stasis and to live within the flow of time." 29 What better place to achieve this than at the edge of an inlet where one is daily in touch with the movement of the

\footnotetext{
24 Lowry, Hear Us, p. 232.

25 Tony Bareham, "Strange Poems of God's Mercy: The Lowry Short Stories," The Art of Malcolm Loury, Anne Smith ed., London, Vision, 1978, p. 159.

26 Lowry, Hear Us, p. 282.

27 Richard Smyer, "A New Look at V.S. Naipaul" Rev. of V.S. Naipaul, by Richard Kelly, and V.S. Naipaul and the West Indies, by Dolly Zulakha Hassan, Contemporary Literature, 33.3, Fall 1992, p. 575.

28 Malcolm Lowry, October Ferry to Gabriola, Vancouver/Toronto, Douglas \& McIntyre, 1988 , p. 4.

29 Sherrill Grace, "The Creative Process: An Introduction to Time and Space in Malcolm Lowry's Fiction," Studies in Canadian Literature, 2.1, Winter 1977, p. 63.
} 
tides. Grace describes the sea as "a pervasive Lowryean symbol of life and motion," 30 and Porteous outlines the beneficial qualities of both sea and forest: "The sea brought . . . a sense of life, of natural abundance" 31 while, "like the sea, the forest provides and nurtures; one can be in harmony with it." 32

The link between the fiction and the author becomes more evident. Porteous argues that "The landscapes of Lowry's novels ... are not merely real or even imagined landscapes, products of his mind; they have in a sense become his mind" 33 and that Lowry's

tormented and deeply divided mind, forever oscillating between elation and despair, redemption and salvation, vested its own distinctive qualities in the landscapes he encountered. These landscapes thus became not merely a backdrop for his life but part of his personality, expressed as the personalities of his characters. ${ }^{34}$

Hints of this appear in Lowry's self-reflexive comments, as in the passage referring to the use to which he has put the cannister and ladder in "Forest Path." This identification recurs in October Ferry when Ethan says that "between the cabin and themselves was a complete symbiosis. They didn't live in it, . . they wore it like a shell" 35 and more profoundly still in the letter to Harvey Burt written from England in which Lowry laments the loss of their "poor pier . . . that gave so much happiness to many and us, was us in a sense" (Lowry's emphasis). ${ }^{36}$ In Porteous's words, "it is here... that the existential outsider finally achieves insideness," 37 but the ever-encroaching city of Vancouver was not about to cease its growth for the sake of Lowry's metaphysical transformation.

In conclusion, while Lowry's descriptions of Vancouver are hardly flattering and less than ambivalent, Porteous's comment

30 Grace, "Creative Process," p. 64.

31 J. Douglas Porteous, "Inscape : Landscapes of the Mind in the Canadian and Mexican Novels of Malcolm Lowry," The Canadian Geographer, 30.2, 1986, p. 125 .

32 Porteous, "Inscape," p. 127

33 Porteous, "Inscape," p. 130

34 Porteous, "Inscape," p. 130

35 Lowry, October Ferry, p. 80.

36 Margerie Bonner Lowry and Harvey Breit, Selected Letters of Malcolm Loury, Philadelphia and New York, J.13. Lippincott, 1965, p. 388.

37 Porteous, "Inscape," p. 126. 
that "Ultimately, Lowry is condemning not the city, but the city as a symbol of modern civilization" 38 remains accurate. The conjunction of this particular city with Lowry's own fears and pleasures makes the conflict especially poignant, as there is also a sense that Lowry cannot finally achieve the "insideness" identified by Porteous, or at least that he cannot maintain that state.

As for the city, it remains. In her 1985 introduction to Vancouver Short Stories, Carole Gerson suggests that "Unlike most large cities, Vancouver has not yet lost the possibility of harmony with its natural environment." ${ }^{39}$ Lowry, thirty-five years earlier, was not so optimistic: he felt that the possibility for harmony was being destroyed with the encroachment of civilization into the outlying regions.

Russell Lowry claimed that his brother Malcolm

was more interested in slime than in silk, in stinks rather than mere smells, in the sordid rather than the sublime. Granted, you can't have one without the other, all the time. He seemed to think he could-wrong way round. The boiling muck under his volcano was more appealing to him than the snow on its summit. He wallowed in one with no more than a passing glance at the other. ${ }^{40}$

In my analysis, this is not a particularly accurate description of how Lowry saw his coastal life. Here, in contrast to Mexico, for perhaps the only time in his life, he was able to give the snow on the mountain summit "more than a passing glance." His vision was ultimately unattainable, but it is the readers who benefit from his attempt to define what might otherwise be lost, taken for granted, or knocked down in favour of the creation of yet another "soulless behemoth." Civilization is still capable of creating "deathscapes": let us hope that we are still capable of at least envisioning the paradisal. ${ }^{41}$

38 Porteous, "Deathscape," p. 43.

39 Carole Gerson ed., Vancouter Short Stories, Vancouver, UBC Press, 1985, p. xiv.

40 Russell Lowry, "Malcolm-A Closer Look," Preface to The Art of Malcolm Lowry, Anne Smith ed., London, Vision, 1978, p. 27.

41 I would also like to thank the helpful, kind, and patient staff at the special Collections section, UBC library, for their assistance and permission to use the reproductions of prints from the Lowry collection that accompanied the original presentation of this paper. 


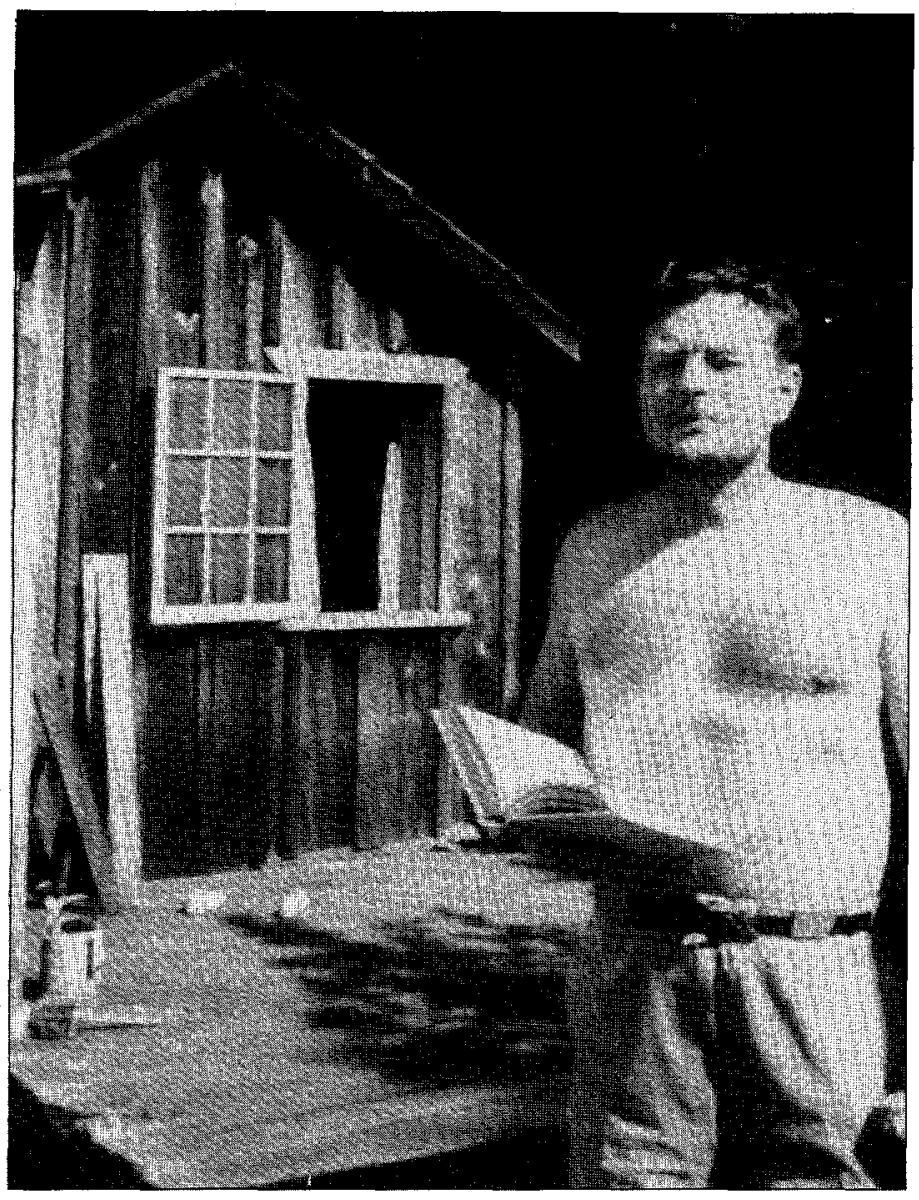

"Malcolm Lowry"

Malcolm Lowry Collection

UBC Special Collections \& University Archives Division 


\section{Bibliography}

Barfham, Tony, Malcolm Lowry, London, Macmillan, 1989.

-, "Strange Poems of God's Mercy: The Lowry Short Stories," in The Art of Malcolm Lowry, Anne Smith ed., London, Vision, 1978. 156-68.

DAHLIF, Hallvard, Varieties of Exile: The Canadian Experience, Vancouver, UBC Press, 1986.

Gerson, Carole, ed., Vancouver Short Stories, Vancouver, UBC Press, 1985. Reprinted 1992.

GracF, Sherrill, "The Creative Process: An Introduction to Time and Space in Malcolm Lowry's Fiction," Studies in Canadian Literature 2.1 (Winter 1977)p. 61-68.

"Malcolm Lowry and the Expressionist Vision," in The Art of Malcolm Lowry, Anne Smith ed., London, Vision, 1978, p. 93-111.

Hunt, Patricia, "North American Pastoral: Contrasting Images of the Garden in Canadian and American Literature," American Studies 23.1 (Spring 1982), p. 39-68.

Lokfnz, Clarissa, "Call It Misadventure," Psalms and Songs, Margerie Lowry ed., New York, New American, 1975, p. 58-71. Originally published in The Atlantic Montbly, June 1970.

Lowly, Malcolm, Hear Us O Lord from Heaven Tby Dwelling Place, Vancouver, Douglas \& McIntyre, 1987. (Copyright 1961 by Margerie Bonner Lowry).

- October Ferry to Gabriola, Vancouver/Toronto, Douglas \& McIntyre, 1988. (Copyright 1970 by Margerie Bonner Lowry).

LowkY, Margerie Bonner and Harvey BRFIT, eds, Selected Letters of Malcolm Lowry, Philadelphia and New York, J.B. Lippincott, 1965. Lowri, Russell, "Malcolm--A Closer Look," Preface to The Art of Malcolm Lowry, Anne Smith ed., London, Vision, 1978, p. 9-27.

New, William, Malcolm Lowry, Canadian Writers Number 11, Toronto/Montreal, McClelland and Stewart, 1971.

Portzous, J. Douglas, "Deathscape: Malcolm Lowry's Topophobic View of the City," The Canadian Geographer 31.1 (1987), p. 3443. 
42

- "Inscape: Landscapes of the Mind in the Canadian and Mexican Novels of Malcolm Lowry," The Canadian Geographer 30.2 (1986): 123-31.

Salloum, Sheryl, Malcolm Lowry: Vancouver Days, Madeira Park, B.C., Harbour, 1987.

SCHERF, Kathleen, ed., The Collected Poetry of Malcolm Lowry, Vancouver, UBC Press, 1992.

SMITH, Anne, ed., The Art of Malcolm Lowry, London, Vision, 1978.

SmYer, Richard, "A New Look at V.S. Naipaul," Rev. of V.S. Naipaul, by Richard Kelly, and V.S. Naipaul and the West Indies, by Dolly Zulakha Hassan, Contemporary Literature 33.3 (Fall 1992), p. 573-81. 